\title{
Correction to: Health concerns and use of biomass energy in households: voices of women from rural communities in Western Uganda
}

Juliet Kyayesimira $^{1^{*}}$ and Florence Muheirwe ${ }^{2}$

\section{Correction to: Energ Sustain Soc (2021) 11:42} https://doi.org/10.1186/s13705-021-00316-2

Following publication of the original article [1], the authors identified an error in the author name Florence Muheirwe.

The incorrect author name is: Muheirwe Florence

The correct author name is: Florence Muheirwe

The author group has been updated above and the original article [1] has been corrected.

\section{Author details}

${ }^{1}$ Department of Biology, Kyambogo University, Kyambogo, P.O. Box 1, Kampala, Uganda. ${ }^{2}$ Institute of Human Settlements Studies, Ardhi University, P. O Box 35176, Dar es Salaam, Tanzania.

Published online: 29 November 2021

\section{Reference}

1. Kyayesimira J, Muheirwe F (2021) Health concerns and use of biomass energy in households: voices of women from rural communities in Western Uganda. Energ Sustain Soc 11:42. https://doi.org/10.1186/ s13705-021-00316-2

\section{Publisher's Note}

Springer Nature remains neutral with regard to jurisdictional claims in published maps and institutional affiliations. original author(s) and the source, provide a link to the Creative Commons licence, and indicate if changes were made. The images or other third party material in this article are included in the article's Creative Commons licence, unless indicated otherwise in a credit line to the material. If material is not included in the article's Creative Commons licence and your intended use is not permitted by statutory regulation or exceeds the permitted use, you will need to obtain permission directly from the copyright holder. To view a copy of this licence, visit http://creativecommons.org/licenses/by/4.0/. The Creative Commons Public Domain Dedication waiver (http://creativecommons.org/publicdomain/zero/1.0/) applies to the data made available in this article, unless otherwise stated in a credit line to the data. 